\title{
The issues of access and restriction
}

\author{
By Cathy Henderson \\ Research Librarian, Harry Ransom Humanities Research Center \\ The University of Texas at Austin \\ and Chair, ACRL Rare Books and Manuscripts Section
}

$\mathrm{T}$ here seems to be a hesitancy on the part of the library profession to applaud absolutely the Huntington Library's decision to make widely available photographic copies it houses of many of the Dead Sea Scrolls. This may stem in part from the fact that standards and guidelines which govern and offer direction to rare book, manuscript, and special collections libraries and librarians on the issue of access are being revised. Consequently, there are no documents to which librarians can refer with assurance for help in assessing the Huntington's move. Of the two documents under revision (the 1987 ACRL "Standards for Ethical Conduct for Rare Book, Manuscript, and Special Collection Libraries" and the ACRL packet of "Guidelines for Manuscripts and Archives"), the new RBMS draft of "Standards of Ethical Conduct for Rare Book, Manuscript, and Special Collections Libraries and Librarians" is closest to completion (hearings are scheduled for Midwinter) and may be quoted meaningfully relative to this event.

The special collections profession, while affirming principles of open access, recognizes that there may be some legitimate constraints on absolute access to research materials. The draft's section on "Limitations of access" states first that access may be denied or limited in order to preserve the "physical or intellectual integrity and safety" of collection materials or to "maintain donor's requirements or those of the holder of the literary rights, or for other legal reasons." Secondly, a library "may not reserve materials for the use of individual scholars except where required by donors' conditions of gift or by decision of the holder of the literary rights in the material." But, if the library itself owns the literary rights, "reservation of materials for the use of individual scholars (although legal) should be avoided."

With reference to this draft standard, knowing that the master negatives came to the Huntington in consequence of a dispute, one would want to know that Mrs. Bechtel had clear title to the negatives and that the Huntington did not abrogate terms of the deposit by releasing the negatives. This requires knowing the terms under which Mrs. Bechtel obtained the photographs from the
Rockefeller Museum in Jerusalem and the terms under which the Huntington accepted the set of master negatives of the Dead Sea Scrolls after she removed them from the Ancient Biblical and Manuscript Center in Claremont, California. These are fairly straightforward issues of legality. But underlying these are less clear issues of appropriateness.

Determining the appropriateness of the Huntington's action is, in part, a question of institutional ethical behavior; of how one rare book and manuscript library behaves towards another. In this instance, the question can be particularized: What responsibilities does a library which acquires duplicates of manuscripts have towards the repository which owns the original manuscripts from which the duplicates were made?

In discussions surrounding the development of a draft, joint ALA/Society of American Archivists "Statement on Access to Original Research Materials in Libraries, Archives and Manuscript Repositories," a key issue was how duplicates of original manuscripts housed elsewhere should be administered. In the absence of an express agreement between libraries (such as might be drawn up for a deliberate exchange of copies), concerns were expressed about the right of the repository housing the copies to further duplicate them without permission of the owner of the original manuscripts or, for that matter, to make them available on-site without permission. No consensus on these issues is manifest in the latest draft and no guidance is offered in the broader draft - "Standards for Ethical Conduct," but they are, nevertheless, legitimate questions about a library's proprietary rights.

The Israeli Antiquities Authority and the Rockefeller Museum in Jerusalem control publication of the Dead Sea Scrolls because they own the physical manuscripts in which the text is embodied. It is a fact that this power effectively passes to the owner of a manuscript containing unpublished text when the text is no longer under copyright protection. What the IAA has done with the power is decried by the scholarly and library community

(Cont. on next page) 
alike. It is behavior, as we have read, which "(although legal) should be avoided."

What mechanisms can the library profession employ to persuade an institution to behave differently? The Huntington Library has offered one example. What, beyond heightened public awareness and pressure, has been gained? The Huntington Library has released only photographic reproductions of the Dead Sea Scrolls. The increased availability of the reproductions does not obviate the need for scholars to have access to the originals because what is being produced, albeit on a schedule unsatisfactory to nearly all, is a scholarly edition of a text. Editors of texts need access to the originals of surviving manuscripts if their edition is to have authority. Running around the Israeli Antiquities Authority, the Rockefeller Museum in Jerusalem, and the scholars privileged to work with the original Dead Sea Scrolls may, in fact, be one way to jump the hurdles they have erected, but it may not help attain the ultimate goal of having democratic access to the original scrolls. The controlling parties need to be convinced that their methods are not conducive to even the chosen editors producing an authoritative text because they stifle the free flow of scholarly inquiry and discourse; but that may require persuasion of a different sort than the Huntington's bold move.

(Moffett cont. from page 632)

That policy has been consistently applied in succeeding years to the thousands of scholars who have drawn on the Huntington's fabled resources, as well as commercial and educational enterprises that have used its materials.

It is that same principle which is embedded in ACRL's and the Society of American Archivists' 1979 "Joint Statement on Access to Original Research Materials:"

"A repository should not deny access to materials to any person or persons, nor grant privileged or exclusive use of materials to any person or person, nor conceal the existence of any body of material from any researcher, unless required to do so by law, donor, or purchase stipulations."

Am I wrong in thinking that most of us simply accept that statement as a commonplace? Do any of us still contend with restrictions that mimic the Dead Sea Scrolls scandal? I sincerely hope not. But should any librarian or archivist find himself or herself in the position we found ourselves in at the Huntington this year, I trust that person will take heart from our experience. Be resolute! Take arms against even a sea of troubles-and by opposing, end them.
(Scrolls cont. from page 631)

ted, access will be dependent solely on the availability of study space and the number of other readers seeking access to the same materials. Use during some periods of the year is predictably very heavy, especially in the summer months.

"In the case of the scrolls archive, the reader will initially be expected to work from images on microfilm. In most cases it will not be necessary to go directly to the master negatives.

"If a person wishes to review the library's scrolls holdings at a distance, he or she can arrange to examine the microfilm set by asking his or her institutional library to secure it from the Huntington on ordinary interlibrary loan. (According to the library's customary practice there may be a modest charge to offset costs of copying, postage, and handling, but the Huntington does not propose to charge a fee for access.)"

\section{What is the current state of events?}

"I think it [the controversy] is over for us," commented Moffett. "The action should shift to the scholars." When asked if he's heard from the Israeli Antiquities Authority, Moffett replied that he's received an invitation from Emmanuel Tov of the Hebrew University in Jerusalem to attend a conference, tentatively scheduled for December 1991, to discuss the issues surrounding the scrolls. Authorized scholars and representatives of those institutions holding images of the scrolls are invited to attend. "The invitation is under consideration," said Moffett, who reported that the "response to the Huntington Library has been overwhelming. Not a single negative comment has come in. It's been a remarkable event to be involved in."-Mary Ellen $K$ Davis, editor and publisher, C\&RL News 